Gazi University
Journal of Science
$\mathrm{http} / /$ dergipark.gov.tr/gujs

\title{
Aggressive Environment Performance of Low Energy Cements Containing Fly Ash
}

\author{
H. Suleyman GOKCE ${ }^{1, *}$ (D), Osman SIMSEK ${ }^{2}$ (D) \\ ${ }^{\prime}$ Bayburt University, Department of Civil Engineering, 69010, Bayburt, Turkey \\ ${ }^{2}$ Gazi University, Department of Civil Engineering, 06100, Ankara, Turkey
}

\author{
Highlights \\ - Boron active belite cement (BABC) is a good alternative for sustainability of cement industry. \\ - Performance against aggressive environments is similar to Portland-composite cement (PCC). \\ - Early strength development of BABC is better compared to that of PCC in presence of fly ash.
}

\begin{tabular}{l} 
Article Info \\
\hline $\begin{array}{l}\text { Received: } 03 / 05 / 2020 \\
\text { Accepted: } 20 / 07 / 2020\end{array}$ \\
Keywords \\
\hline $\begin{array}{l}\text { Active belite cement } \\
\text { Fomposite cement } \\
\text { Compressive strength } \\
\text { Aggressive } \\
\text { environments }\end{array}$
\end{tabular}

\section{INTRODUCTION}

The responsibility of cement industry in terms of carbon footprint is reached to $7 \%$ of global anthropogenic emissions due to around $850 \mathrm{~kg}$ of $\mathrm{CO}_{2}$ emission per ton production of cement [1-4]. This emission following by depleting natural resources and fossil fuel deposits is among of the most serious environmental problems facing human being [5]. After 1990s, $\mathrm{CO}_{2}$ emissions were limited with Kyoto Protocol or other similar agreements. Hereby, energy saving resulting in the environmental benefits increasingly became an important issue in cement manufacture processes in last decade.

According to Popescu et al. [6], a low lime saturation factor of farine in production of clinker could result in reducing energy consumption and simultaneously less releasing $\mathrm{CO}_{2}$. The alteration of kiln feed will lead to the increasing belite phase and the decreasing alite phase. Belite-based cements are known as ecofriendly materials thanks to the $10 \%$ less $\mathrm{CO}_{2}$ emissions [7-9]. In production of these cements, clinkering temperature can be reduced $120-160{ }^{\circ} \mathrm{C}$ when compared to ordinary Portland cement [6].

Superior long-term strength and durability characteristics could be achieved if alite-based clinker is replaced by belite-based clinker because of a reduction in total $\mathrm{Ca}(\mathrm{OH})_{2}$ formed during cement hydration [10]. Hydration products of belite phase (see Equation (1)) are relatively more durable than those of alite phase (see Equation (2)) in aggressive environments because of its relatively lower $\mathrm{Ca}(\mathrm{OH})_{2}$ product 
amount that is prone to degradation more than C-S-H product. The reactions taken place between the $\mathrm{Ca}(\mathrm{OH})_{2}$ products and solutions of ammonium nitrate and sodium sulfate sources result in gypsum formation and other soluble products as seen from Equations (3) and (4). Thus, a trend has been resulted in reduction of $\mathrm{Ca}(\mathrm{OH})_{2}$ content in cementitious products as much as possible in the field [11]

$$
\begin{array}{lll}
2 \mathrm{C}_{2} \mathrm{~S} \text { (belite) }+9 \mathrm{H}_{2} \mathrm{O} & \rightarrow & \mathrm{C}-\mathrm{S}-\mathrm{H}+\mathrm{Ca}(\mathrm{OH})_{2} \\
2 \mathrm{C}_{3} \mathrm{~S} \text { (alite) }+11 \mathrm{H}_{2} \mathrm{O} & \rightarrow & \mathrm{C}-\mathrm{S}-\mathrm{H}+3 \mathrm{Ca}(\mathrm{OH})_{2} \\
\mathrm{Ca}(\mathrm{OH})_{2}+2 \mathrm{NH}_{4} \mathrm{NO}_{3} & \rightarrow & \mathrm{Ca}\left(\mathrm{NO}_{3}\right)_{2}+2 \mathrm{NH}_{3}+2 \mathrm{H}_{2} \mathrm{O} \\
\mathrm{Ca}(\mathrm{OH})_{2}+\mathrm{Na}_{2} \mathrm{SO}_{4}+2 \mathrm{H}_{2} \mathrm{O} & \rightarrow & \mathrm{CaSO}_{4} \cdot 2 \mathrm{H}_{2} \mathrm{O}(\text { gypsum })+2 \mathrm{NaOH}
\end{array}
$$

It is known that the belite-based cements reduce the hydration heat and the heat evolution. Sağlik et al. [12] indicated in their study that boron active belite cement has the less rate of hydration and heat of hydration compared to ordinary plain cement and fly ash incorporating cement. In addition, according to Stark et al. [13] as cited by Lawrence [14], almost $150 \mathrm{~kJ} / \mathrm{kg}$-less theoretical heat of formation could be achieved in belite-based cement compared to a conventional alite cement.

Some by products containing $\mathrm{H}_{3} \mathrm{BO}_{3}$ and borates are used for producing boron active belite cement clinker that is an exclusive cement clinker bearing 3-4\% $\mathrm{B}_{2} \mathrm{O}_{3}$ [15-17]. Thus, superior neutron shielding ability can also be achieved by the use of such cement product according to boron free counterparts [18].

In general, studies in the field have been focused on cementitious systems having high volume fly ash to present some advantageous such as superior strength and durability characteristics, lower permeability, lower heat of hydration and thermal cracking in addition to the environmental benefits [19-23]. However, the reaction degree of fly ash in early strength gain for high volume fly ash cementitious binders is still questioned by many researchers [24-27]. Moreover, Lam et al. [24] stated that there are remarkable differences between low-volume (below 25\%) and high-volume (close to 50\% and over) fly ash-bearing binders, and the hydration mechanism of high volume fly ash could be more complex. Although some chemical approaches are used to accelerate early reactivity the systems having high volume fly ash, some durability problems can be arisen [28].

For the aforementioned reasons, environmentally friendly cements are required to be research further to response the sustainability goals of construction sector. Hence, the present study focused on the compressive strength performance of boron active belite cement and an alternative low energy cement blending with fly ash after exposure to the aggressive solutions reaching up to 90 days.

\section{MATERIAL METHOD}

\subsection{Materials}

A boron active belite cement (BABC) which was manufactured by Göltaş Cement (Isparta/Turkey) was supplied from Turkish General Directorate of State Hydraulic Works (Ankara/Turkey) in airproof special packs. A Portland composite cement (PCC) which is classified as CEM II/B-M (P-L) 32.5 R according to EN 197-1 [29] was obtained from Baştaş Cement to be use as an alternative low energy cement. A cementitious fly ash (class F) gathered from Yatağan Thermal Power Plant (Turkey) was used as a supplementary cementitious material. Table 1 presents chemical and physical properties of these materials. 
Table 1. Chemical and physical properties of cements and fly ash (FA)

\begin{tabular}{cccc}
\hline Composition $(\%)$ & $\mathrm{BABC}[12]$ & $\mathrm{PCC}$ & $\mathrm{FA}$ \\
\hline $\mathrm{SiO}_{2}$ & 19.1 & 32.31 & 45.38 \\
$\mathrm{Al}_{2} \mathrm{O}_{3}$ & 4.68 & 7.05 & 19.74 \\
$\mathrm{~F}_{2} \mathrm{O}_{3}$ & 3.42 & 3.30 & 7.47 \\
$\mathrm{CaO}$ & 57.1 & 47.33 & 15.22 \\
$\mathrm{~B}_{2} \mathrm{O}_{3}$ & 3.0 & - & - \\
$\mathrm{MgO}$ & 1.32 & 1.21 & 2.79 \\
$\mathrm{SO}$ & 2.68 & 2.72 & 5.63 \\
$\mathrm{Na}_{2} \mathrm{O}$ & 0.34 & 1.30 & 0.57 \\
$\mathrm{~K}_{2} \mathrm{O}$ & 0.78 & 1.07 & 2.24 \\
$\mathrm{LOI}$ & 3.82 & 2.47 & 0.87 \\
\hline Blaine fineness $\left(\mathrm{cm}^{2} / \mathrm{g}\right)$ & 3562 & 4198 & 3392 \\
Density $\left(\mathrm{g} / \mathrm{cm}^{3}\right)$ & 3.09 & 2.98 & 1.940 \\
\hline
\end{tabular}

\subsection{Methods}

Mortar mixtures were prepared and tested in accordance with EN 196-1 [30] by using CEN reference sand. In mixture series, fly ash (FA) was replaced at $0 \%, 10 \%, 20 \%$ and $30 \%$ by weight of the cements, respectively. The labels of mixtures were coded with cement type and the amount of FA. As an example, the mix containing $10 \%$ FA bearing-BABC was named as BABC-10. Table 2 presents all mixing details for these mixture series.

Table 2. Mix proportions

\begin{tabular}{ccccccccc}
\hline Ingredients & BABC-0 & BABC-10 & BABC-20 & BABC-30 & PCC-0 & PCC-10 & PCC-20 & PCC-30 \\
\hline Cement, g & 450 & 405 & 360 & 450 & 405 & 360 & 315 & 315 \\
Fly ash, g & - & 45 & 90 & 135 & - & 45 & 90 & 135 \\
Aggregate, g & 1350 & 1350 & 1350 & 1350 & 1350 & 1350 & 1350 & 1350 \\
Water, ml & 225 & 225 & 225 & 225 & 225 & 225 & 225 & 225 \\
W/b ratio & 0.5 & 0.5 & 0.5 & 0.5 & 0.5 & 0.5 & 0.5 & 0.5 \\
\hline
\end{tabular}

A constant consistency of cement mortars was achieved by modifying with various amount of superplasticizer. $\mathrm{W} / \mathrm{b}$ ratio of cement mortars was kept constant by the required water adjustments derived from water content of superplasticizer. $40 \times 40 \times 160-\mathrm{mm}$ prismatic molds were used for preparation of mortar specimens. The mortars were placed in two layers by using vibrating table. After 24 -hour resting in laboratory condition at $20 \pm 2{ }^{\circ} \mathrm{C}$ and $\geq 90 \% \mathrm{RH}$, the samples were demoulded and cured in tapping water (Ref), sea water (Sea) supplied from Black Sea (located between eastern Europe, the Caucasus and Western Asia), 5\% of sodium sulphate solution (Sod) and 5\% ammonium nitrate solution (Amm) until 7, 28 and 90 days at $20 \pm 2{ }^{\circ} \mathrm{C}$.

\section{THE RESEARCH FINDINGS AND DISCUSSION}

\subsection{The Research Findings}

Fly ash replacement reduces the compressive strength development of the BABC and PCC mortars cured in tapping water, especially in early ages as seen in Figure 1. The reduction in compressive strength of the BABC having FA was highly rehabilitated in elongated curing time (90 days). However, PCC mortars still present the remarkable reductions in compressive strength with increasing FA incorporation at 90 days. 


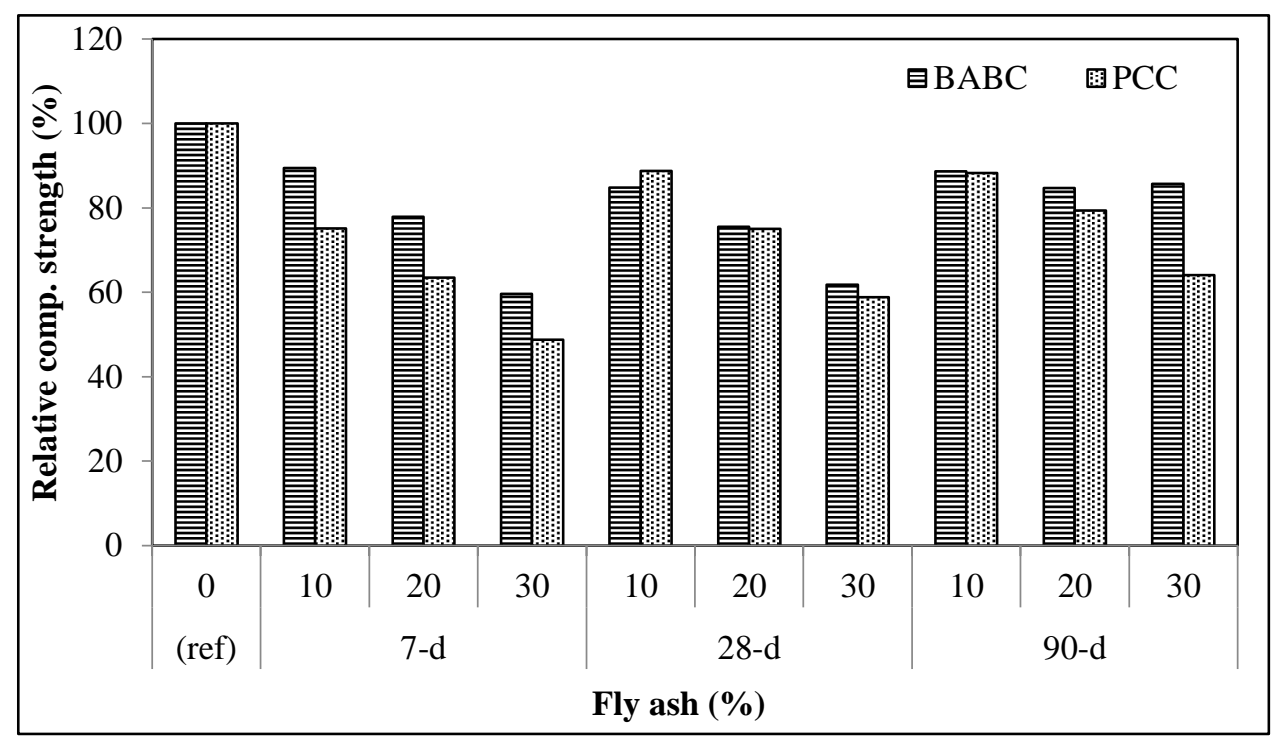

Figure 1. Relative effect of fly ash on compressive strength of BABC and PCC mortars

In the study, the compressive strength values of BABC and PCC mortar mixtures were determined after exposure to aggressive environment conditions. Figure 2 shows compressive strength of the cements without FA in aggressive solutions at 7,28 and 90 days. At early age (7-day), there is no significant effect of aggressive environment on the compressive strength of BABC and PCC mortar mixtures. Aggressive environment increasingly deteriorated the long-term compressive strength results of BABC. However, the deterioration was observed at 90-day for PCC. Sea water condition impaired the results remarkably more than that of sodium sulphate-bearing and ammonium nitrate-bearing environments.

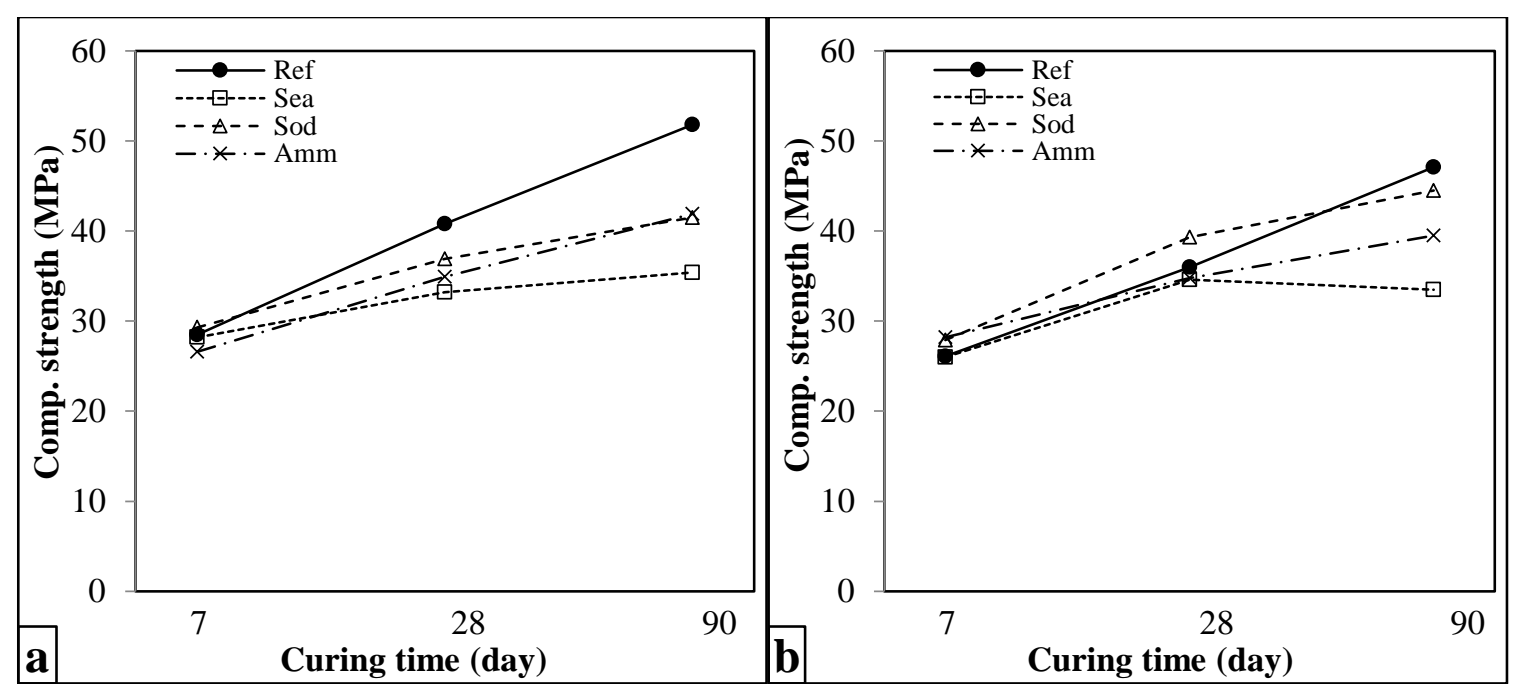

Figure 2. Compressive strength of mortars prepared with a) BABC and b) PCC

The relative compressive strength results of the both cement mortars without FA were constituted in Figure 3 by considering specimens cured in tapping water as reference (relatively $100 \%$ at any curing time). The deterioration degree of the both cements is almost similar at 90 days in sea water and $\% 5$ ammonium nitrate solution. In general, the results show that performance of BABC against aggressive environment is poorer than that of PCC. Sea water remarkably impaired the compressive strength of the cements compared to sodium sulphate and ammonium nitrate solutions. 


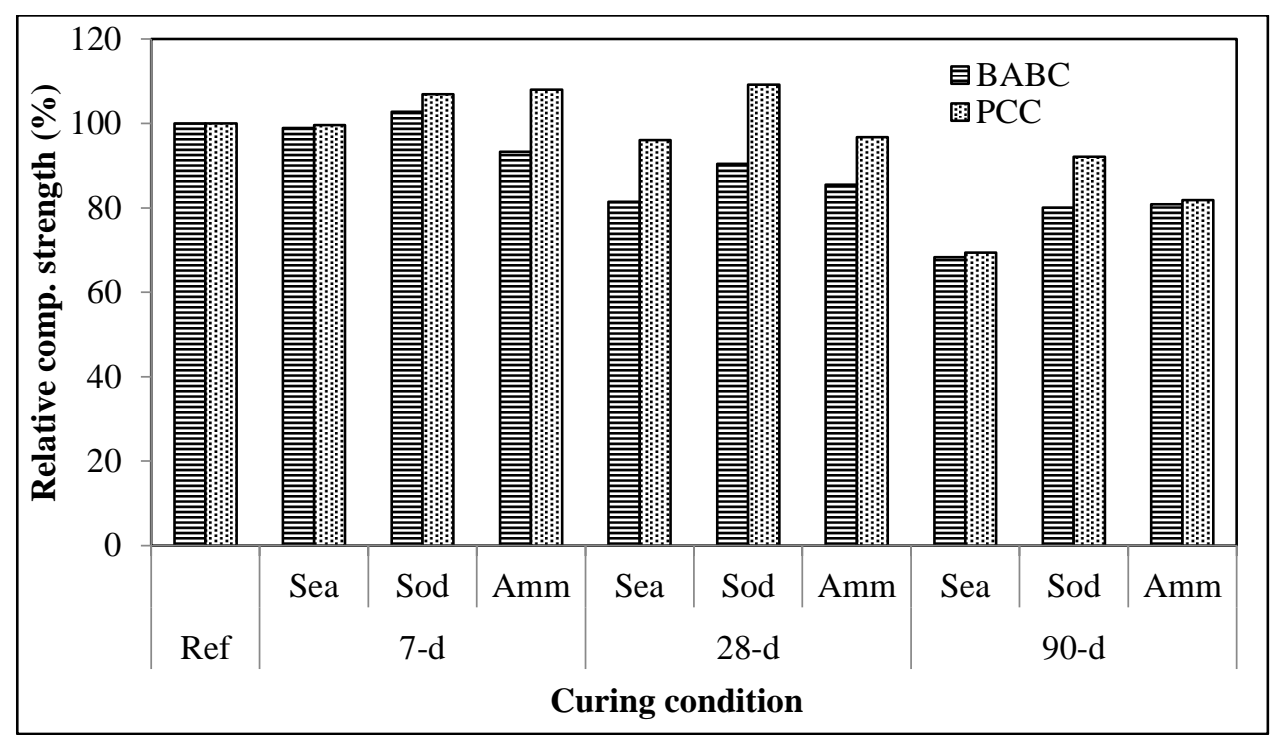

Figure 3. Relative compressive strength of cement mortars without FA

The compressive strength results of the cement mortar having 10\% FA are presented in Figure 4. It is seen that there is no significant effect of aggressive solutions on the early age ( 7 days) compressive strength of the cements having 10\% FA. However, the aggressive environment remarkably disturbs their strength performance at later ages ( 28 and 90 days). The deterioration of sea water and ammonium nitrate solution was found almost similar at 90 -day specimens with $10 \%$ FA.

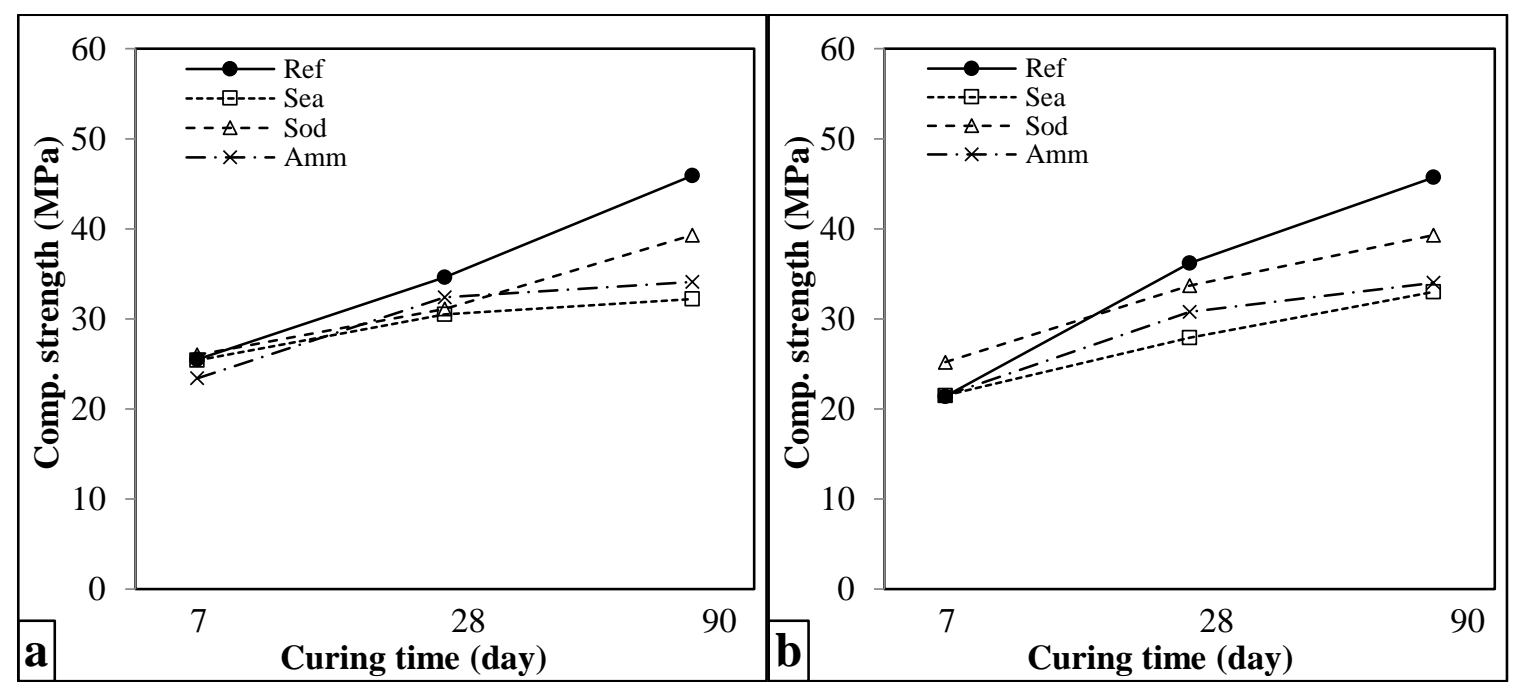

Figure 4. Compressive strength of mortars prepared with a) BABC and b) PCC having $10 \% \mathrm{FA}$

The relative compressive strength results of the both cement mortars with 10\% FA were constituted in Figure 5 by considering specimens cured in tapping water as reference (relatively $100 \%$ at any curing time). Residual compressive strengths show that resistance of the both cements against aggressive environment is almost similar at 90 days in case of $10 \%$ FA incorporation. Results show that 90 -day strength losses of $\mathrm{BABC}$ and PCC with 10\% FA are more pronounced in sea water and ammonium nitrate solution rather than in sodium sulphate solutions. 


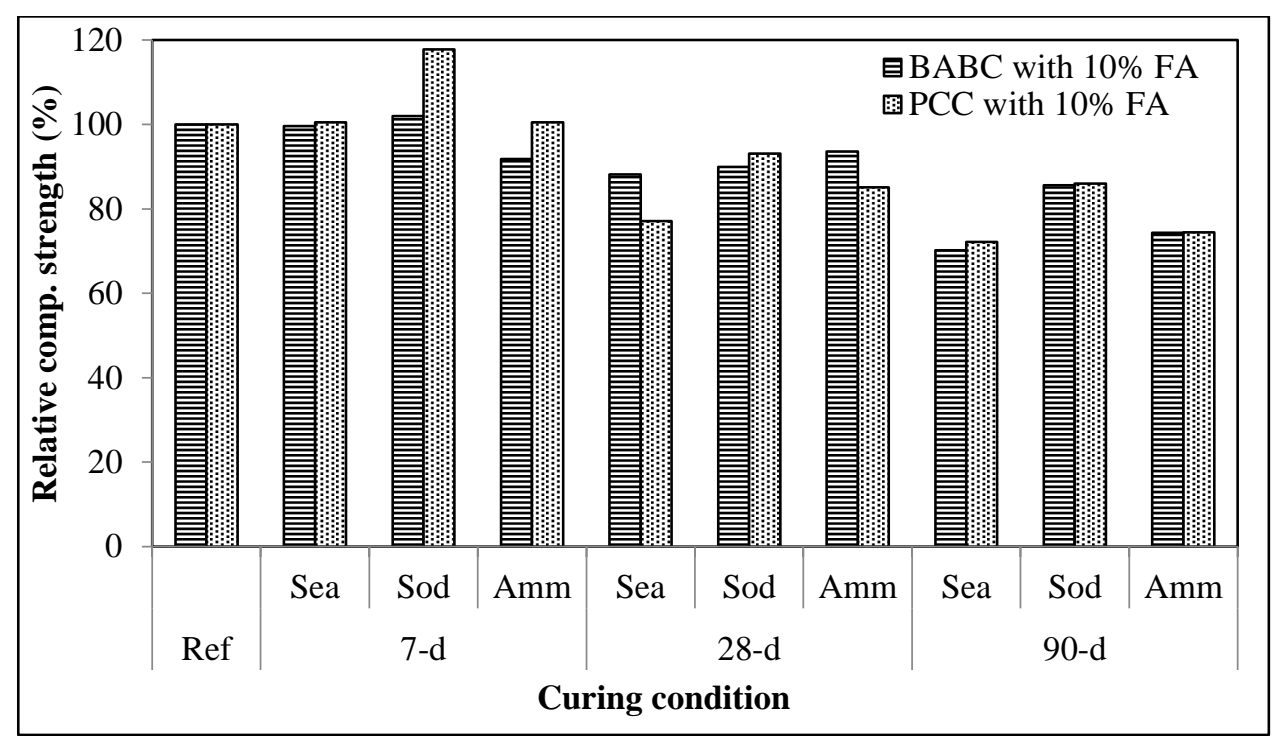

Figure 5. Relative compressive strength of cement mortars with $10 \% \mathrm{FA}$

The compressive strength results of cement mortars having 20\% FA are presented in Figure 6. Aggressive environments do not impair early age compressive strength of the cements having $20 \%$ FA. However, further exposure to the aggressive environment disturbs the compressive strength results of the cements.

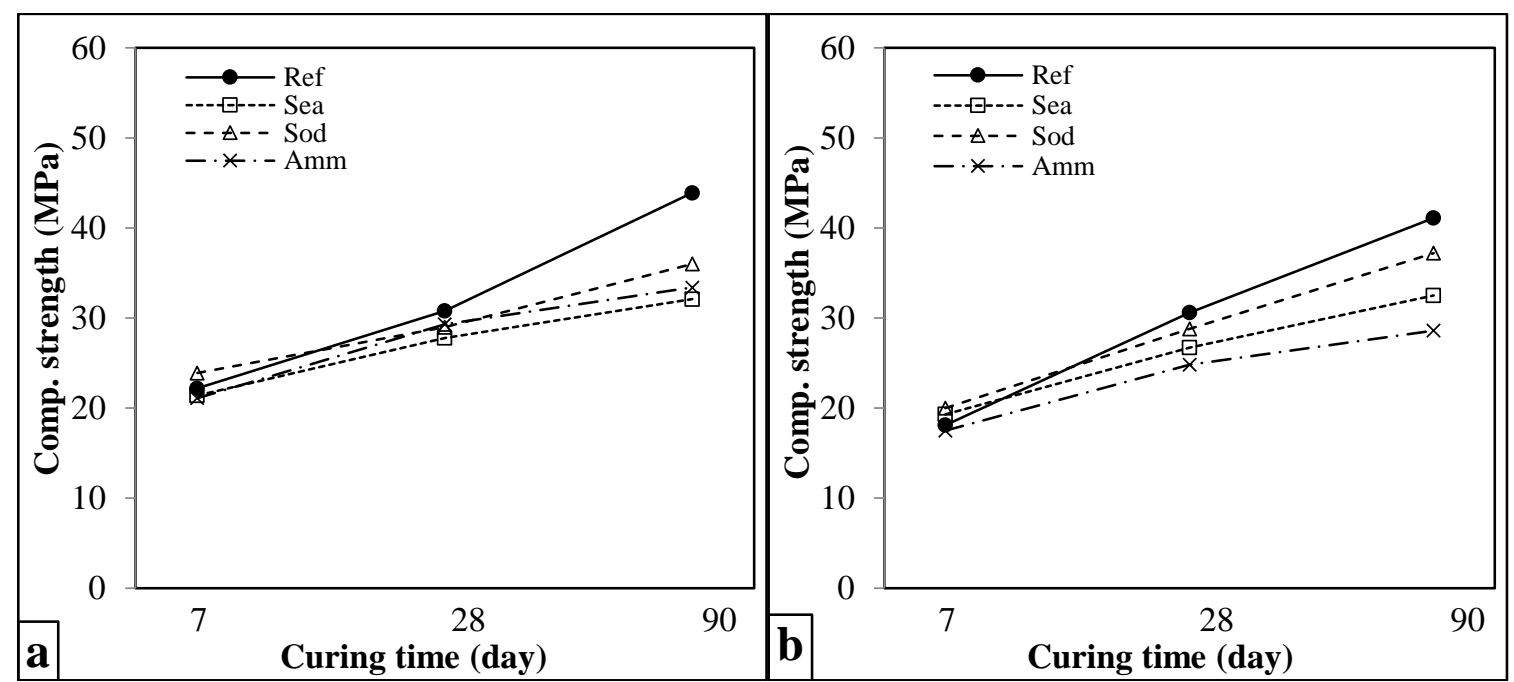

Figure 6. Compressive strength of mortars prepared with a) BABC and b) PCC having 20\% FA

The relative compressive strength results of the both cement mortars with $20 \%$ FA were constituted in Figure 7 by considering specimens cured in tapping water as reference (relatively $100 \%$ at any curing time). Results show that 90-day strength losses of BABC and PCC with 20\% FA are more pronounced in sea water and ammonium nitrate solution rather than in sodium sulphate solutions. 


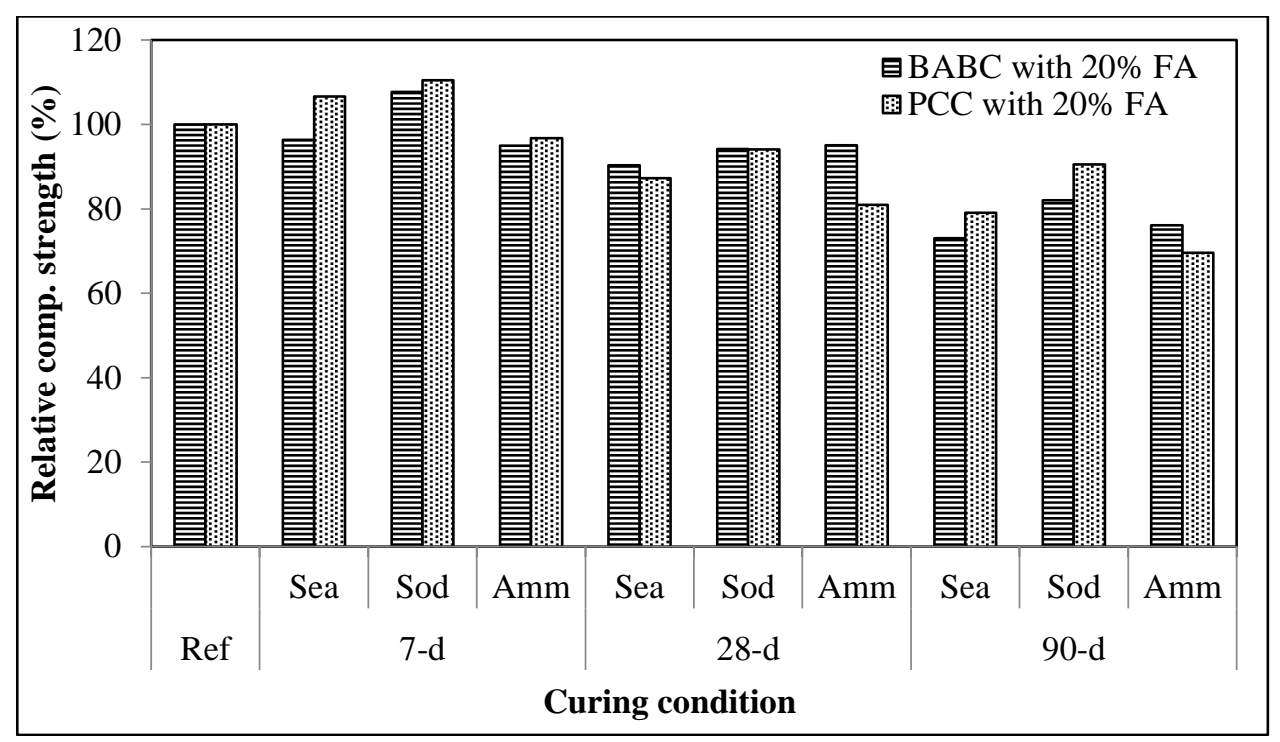

Figure 7. Relative compressive strength of cement mortars with $20 \% \mathrm{FA}$

The compressive strength results of the cement mortars having 30\% FA are presented in Figure 8 . It is seen that there is no remarkable effect of aggressive environments on the early age compressive strength of the cements having 30\% FA. Compressive strength of the PCC specimens cured in sodium sulphate solutions was found similar to specimens cured in tapping water. have no effect on the results of PCC with $30 \%$ FA at any age. Aggressive environment severely disturbed the compressive strength of BABC at ultimate age (90 days).

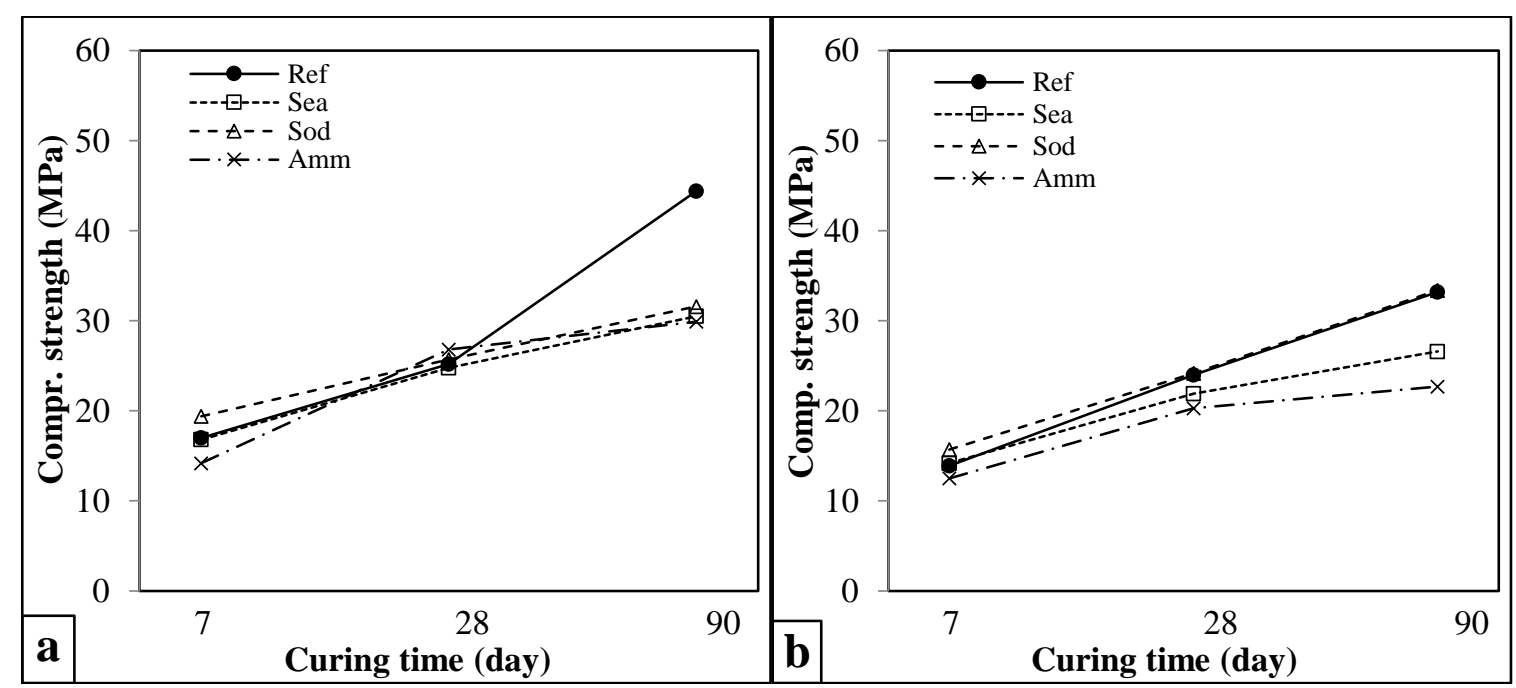

Figure 8. Compressive strength of mortars prepared with a) BABC and b) PCC having $30 \% \mathrm{FA}$

The relative compressive strength results of the both cement mortars with $30 \%$ FA were constituted in Figure 9 by considering specimens cured in tapping water as reference (relatively $100 \%$ at any curing time). Results show that aggressive environment significantly impaired the 90-day compressive strength of BABC with $30 \%$ FA. The losses were relatively found less for PCC counterparts in sea water and sodium sulphate solution than that of BABC. Aggressive environment resistance of PCC against sodium sulphate solution was found satisfactory at $30 \% \mathrm{FA}$ incorporation. 


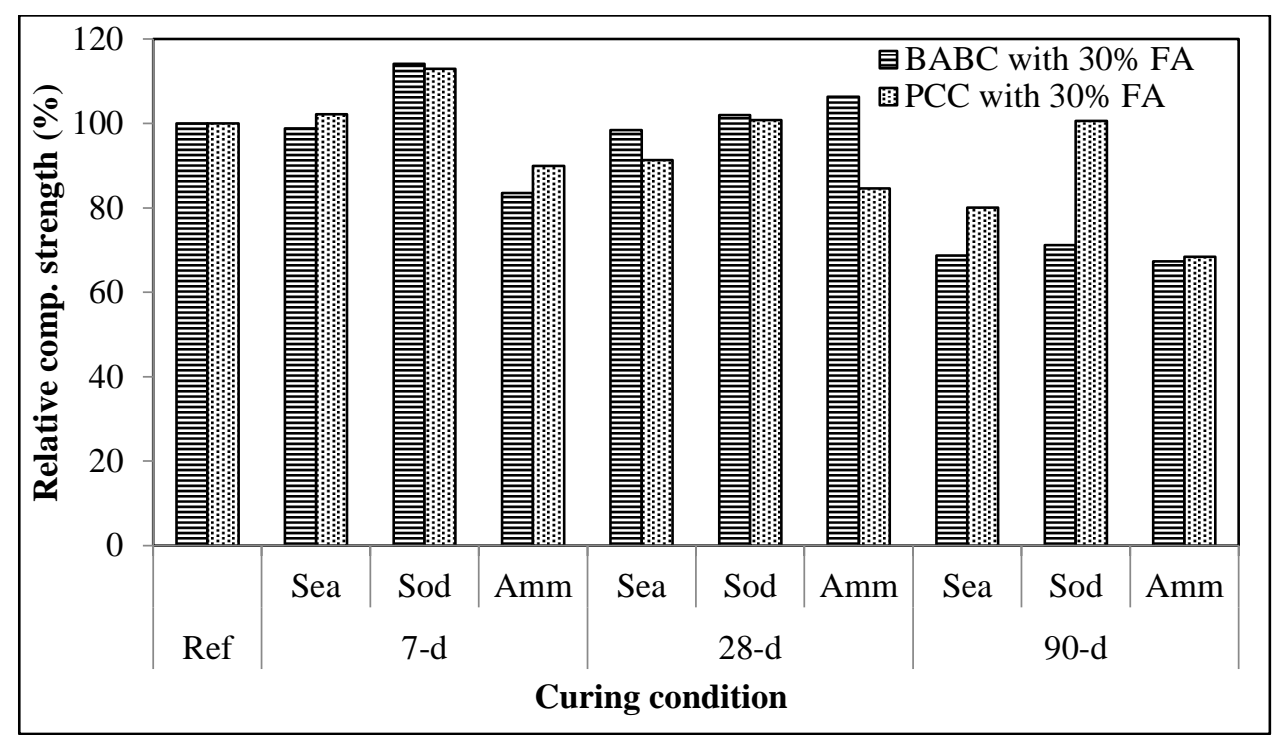

Figure 9. Relative compressive strength of cement mortars with $30 \%$ FA

\subsection{Analyses and Discussions}

The plain and reinforced concrete members are mostly confronting to physical and chemical deteriorations for along service life due to the placing in contact with or close to marine environments [31]. In our study, sea water was found the most aggressive environment at later ages for both cement types without FA, although chemical degradation is only realized rather physical effects such as wetting-drying and freezingthawing. Due to presence of chlorine and sulphate ions, sea water makes hydration products of cement in mortars and concretes susceptible to its attack [32]. Especially, the degradation of C-S-H products results in substantial loss of strength.

Li [28] stated that sulphate activation may decrease the durability due to high ettringite contents. Sodium sulphate increases the $\mathrm{pH}$ of pore solution in early age, and thus, it is help to pozzolanic reaction of FA in high volume fly ash cementitious systems [25]. As stated by Al-Amoudi [33], $\mathrm{C}_{3} \mathrm{~S} / \mathrm{C}_{2} \mathrm{~S}$ ratio controls the sulphate resistance of cement. $\mathrm{C}_{2} \mathrm{~S}$ content of cement produces a significantly lower amount of $\mathrm{CH}$ than that of $\mathrm{C}_{3} \mathrm{~S}$ [34]. The reaction of sulphate ion with the produced $\mathrm{CH}$ results in gypsum formation. The deterioration process leads to reduction of stiffness and strength due to the expansion and crack formation in matrix. Since pozzolans consumes the $\mathrm{CH}$ produced, the amount of gypsum products will be lower in the blended cements according to the plain cements [35]. Moreover, fly ashes have the physically filling potential on spaces, and contribute to the ettringite formations [36]. The cases express the positive effect of sodium sulphate environment at early age compressive strength, and losses at long-term compressive strength in our study. Thus, resistance of both cements with and without FA against sodium sulphate shows difference.

Alkalinity in pore solution of hydrated cement paste significantly affected with the presence of FA by depending its alkali, calcium and silica contents [37]. As seen from our study, FA incorporation increases damage of ammonium nitrate solution at later age compressive strength of cements. Reaction products (calcium nitrate and ammonia) of ammonium nitrate with $\mathrm{CH}$ can be easily dissolved in water [38]. The high $\mathrm{pH}(\geq 12.5)$ of pore solution normally presents a very alkaline environment in cement paste matrix [39]. Ammonium nitrate-bearing waters with a lower $\mathrm{pH}$ characterizes acidic environments for cement products. Therefore, the dissolving of $\mathrm{CH}$ structures in the ammonium nitrate-bearing environment is more severe compared to that in water with ion-free [38].

\section{RESULTS}

The following conclusions could be drawn from the results of boron active belite cement and Portlandcomposite cement mortars with and without FA in aggressive environments: 
- Sea water and 5\% ammonium nitrate solution caused increasingly reduction in compressive strength results of these mortars produced by boron active belite cement and Portland-composite cement mortars with and without FA up to 90 days.

- $5 \%$ sodium sulphate solution acts as an activator in early strength of the cement mortars. However, it causes reduction in later age compressive strength of the mortars.

- In general, it can be said that aggressive environment robustness of the boron active belite cement is too closed the Portland-composite cement, or some extent poorer.

- Sodium sulphate robustness of the cements is generally better than that of sea water and ammonium nitrate especially at later ages.

- It is seen that compressive strength development of the boron active belite cement with low content fly ash is promising instead of high volume fly systems.

- Boron active belite cement with fly ash is recommended as a cement which is low heat of hydration, especially in mass concrete and hot weather concreting applications.

\section{CONFLICTS OF INTEREST}

No conflict of interest was declared by the authors.

\section{REFERENCES}

[1] Hendriks, C. A., Worrell, E., Price, L., Martin, N., Ozowa Meida, L., De Jager, D., Riemer, P., "Emission reduction of greenhouse gases from the cement industry", 4th International Conference on Greenhouse Gas Control Technologies, Interlaken, Switzerland, 939-944, (1998).

[2] Worrell, E., Price, L., Martin, N., Hendriks, C., Ozowa Meida, L., "Carbon dioxide emissions from the global cement industry", Annual Review of Energy and the Environment 26: 303-329, (2001).

[3] Gartner, E., "Industrially interesting approaches to "low- $\mathrm{CO}_{2}$ " cements", Cement and Concrete Research 34: 1489-1498, (2004).

[4] Damtoft, J. S., Lukasik, J., Herfort, D., Sorrentino, D., Gartner, E. M., "Sustainable development and climate change initiatives", Cement and Concrete Research, 38: 115-127, (2008).

[5] Taylor, H. F. W. “Cement Chemistry”. London: Academic Press, (1990).

[6] Popescu, C. D., Muntean, M., Sharp, J. H., "Industrial trial production of low energy belite cement", Cement and Concrete Composites, 25: 689-693, (2003).

[7] Chatterjee, A. K., "High belite cements-present status and future technological options: Part I", Cement and Concrete Research, 26: 1213-1225 (1996).

[8] Guerrero, A., Goñi, S., Campillo, I., Moragues, A., "Belite cement clinker from coal fly ash of high Ca content: Optimization of synthesis parameters", Environmental Science \& Technology, 38: 3209-3213, (2004).

[9] De La Torre, A. G., Aranda, M. A. G., De Aza, A. H., Pena, P., De Aza, S., "Belite portland clinkers: Synthesis and mineralogical analysis", Boletin De La Sociedad Española de Cerámica y Vidrio, 44: 185-191, (2005).

[10] Kacimi, L., Simon-Masseron, A., Salem, S., Ghomari, A., Derriche, Z., "Synthesis of belite cement clinker of high hydraulic reactivity", Cement and Concrete Research, 39: 559-565, (2009).

[11] Li, Z. “Advanced Concrete Technology”. USA: John Wiley \& Sons Inc., (2011). 
[12] Sağlık, A., Sümer, O., Tunç, E., Kocabeyler, M. F., Çelik, R. S., "Boron modified active belite (BAB) cement and its applicability for DSI projects", DSI Technical Bulletin, 105: 1-22, (2009).

[13] Stark, J., Müller, A., Schrader, R., Rümpler, K., "Existence conditions of hydraulically active belite cement”, Zement-Kalk-Gips, 34: 476-481, (1981).

[14] Lawrence, C. D., "The production of low-energy cement”, pp. 421-470, Hewlett, P. C. (Ed.). "Lea's Chemistry of Cement and Concrete". 4th ed., Elsevier Science and Technology Books, (2004).

[15] Yeşilmen, S., Gürbüz, A., "Evaluation of boron ore in cement production", Materials and Manufacturing Processes, 27: 1245-1250, (2012).

[16] Kunt, K., Dur, F., Ertınmaz, B., Yıldırım, M., Derun, E., Pişkin, S., "Utilization of boron waste as an additive for cement production", Celal Bayar University Journal of Science, 11: 383-389, (2015).

[17] Aydın, A. C., Haşiloğlu Aras, Ü. G., Kotan, T., Öz, A., "Effect of boron active belite cement on the compressive strength of concrete exposed to high temperatures", Journal of Civil, Construction and Environmental Engineering, 3: 47-52, (2018).

[18] Gökçe, H. S., "High temperature resistance of boron active belite cement mortars containing fly ash", Journal of Cleaner Production, 211: 992-1000, (2019).

[19] Bilodeau, A., Malhotra, V. M., "High-volume fly ash system: Concrete solution for sustainable development", ACI Materials Journal, 97: 41-48 (2000).

[20] Şahmaran, M., Li, V. C., "Durability properties of micro-cracked ECC containing high volumes fly ash", Cement and Concrete Research, 39: 1033-1043 (2009).

[21] Qiang, W., Peiyu, Y., Jinging, F., "Design of high-volume fly ash concrete for massive foundation slab", Magazine of Concrete Research, 65: 71-81, (2013).

[22] Park, K.-B., Noguchi, T., "Effects of mixing and curing temperature on the strength development and pore structure of fly ash blended mass concrete", Advances in Materials Science and Engineering, 2017: 3452493, (2017).

[23] Hemalatha, T., Ramaswamy, A., "A review on fly ash characteristics-Towards promoting high volume utilization in developing sustainable concrete", Journal of Cleaner Production, 147: 546-559, (2017).

[24] Lam, L., Wong, Y. L., Poon, C. S., "Degree of hydration and gel/space ratio of high-volume fly ash/cement systems", Cement and Concrete Research, 30: 747-756, (2000).

[25] Zhang, Y. M., Sun, W., Yan, H. D., "Hydration of high-volume fly ash cement pastes", Cement and Concrete Composites, 22: 445-452, (2000).

[26] Yazıc1, H., Aydın, S., Yiğiter, H., Baradan, B., "Effect of steam curing on class C high-volume fly ash concrete mixtures", Cement and Concrete Research, 35: 1122-1127, (2005).

[27] Hemalatha, T., Sasmal, S., "Early-age strength development in fly ash blended cement composites: Investigation through chemical activation", Magazine of Concrete Research, 71: 260-270, (2019).

[28] Li, G., "Properties of high-volume fly ash concrete incorporating nano-SiO2", Cement and Concrete Research, 34: 1043-1049, (2004).

[29] EN 197-1, "Cement - Part 1: Composition, specifications and conformity criteria for common cements, European Committee for Standardization”, CEN, Brussels, (2011). 
[30]EN 196-1, "Methods of testing cement - Part 1: Determination of strength, European Committee for Standardization", CEN, Brussels, (2016).

[31] Yiğiter, H., Yazıcı, H., Aydın, S., "Effects of cement type, water/cement ratio and cement content on sea water resistance of concrete", Building and Environment, 42: 1770-1776, (2007).

[32] Bai, J., Wild, S., Sabir, B. B., "Chloride ingress and strength loss in concrete with different PC-PFAMK binder compositions exposed to synthetic seawater", Cement and Concrete Research, 33: 353-362, (2003).

[33] Al-Amoudi, O. S. B., "Attack on plain and blended cements exposed to aggressive sulfate environments", Cement and Concrete Research, 24: 305-316, (2002).

[34] Sahmaran, M., Kasap, O., Duru, K., Yaman, I.O., "Effects of mix composition and water-cement ratio on the sulfate resistance of blended cements", Cement and Concrete Composites, 29: 159-167, (2007).

[35] Al-Amoudi, O. S. B., Maslehuddin, M., Saadi, M. M., "Effect of magnesium sulfate and sodium sulfate on the durability performance of plain and blended cements", ACI Materials Journal, 92: 15-24, (1995).

[36] Berry, E. E., Hemmings, R. T., Cornelius, B. J., "Mechanism of hydration reactions in high volume fly ash pastes and mortars", Cement and Concrete Composites, 12: 253-261, (1990).

[37] Shehata, M. H., Thomas, M. D. A., Bleszynski, R. F., "The effects of fly ash composition on the chemistry of pore solution in hydrated cement pastes", Cement and Concrete Research, 29: 1915-1920, (1999).

[38] Schneider, U., Chen, S.-W., "Behavior of high-performance concrete under ammonium nitrate solution and sustained load", ACI Materials Journal, 96: 47-51, (1999).

[39] Torrenti, J. M., Nguyen, V. H., Colina, H., Le Maou, F., Benboudjema, F., Deleruyelle, F., “Coupling between leaching and creep of concrete", Cement and Concrete Research, 38: 816-821, (2008). 